\title{
Effects of Black Cumin (Nigella sativa L.) on patients with cancer and tumor: A systematic Review
}

\author{
Mohammad Asadul Habibi,2,*, Akibul Islam Chowdhury'1, Monia Afroze ${ }^{1}$, Tanjina Rahman ${ }^{1}$ \\ ${ }^{1}$ Department of Food Technology and Nutrition Science, Noakhali Science and Technology University, Naokhali-3814, Bangladesh \\ 2Department of Nutrition, World Vision International, Cox’s Bazar, Bangladesh
}

\begin{abstract}
Experimental studies demonstrated a positive effect of administration of Nigella sativa L. (Black cumin) and its active chemical components on cancer and tumor through the antioxidant and anticancer activity. This study aimed to determine the beneficial effect of the use of black cumin in patients with cancer and tumor. This systematic review includes 4 randomized controlled trials that investigated the effect of the administration of black cumin in human cancer. Articles were searched in PubMed, Cochrane library, Semantic scholar and directory of open access journal (DOAJ), open grey and grey literature report databases for studies from 1983 to 2020 before May using the following keywords, Nigella sativa, black cumin, cancer, tumor, etc. The results examined that $N$. sativa is much effective in treating breast cancer, gastrointestinal cancer, brain tumor, and acute myeloid leukemia. According to the limited evidence from the study, black cumin may have favorable effects on cancer and tumor. However, more research is needed on different types of cancer to confirm and establish the above findings.
\end{abstract}

Keywords: Nigella sativa L., Cancer, Tumors, Black cumin

\section{Introduction}

Nigella sativa L. or black cumin has become one of those popular medicinal plants that have been used for centuries for health benefits. Nigella sativa L. belongs to the Ranunculaceae family and is an annual herb with 8-12-inch-high pinnate, stratified leaves [1]. New products are also advocated from natural sources, as it is estimated that more than 300,000 herbal species exist globally among them only $15 \%$ have been explored for their pharmacological potential [2]. N. sativa, along with many medicinal plants (Ranunculaceae) has been considered as one of the most appreciated nutrient-rich herbs in the world's history, and numerous scientific studies are under its way to justify the typically claimed use of this species' small seed [3,4].N. sativa is an herbaceous plant with wonderful therapeutic effects, such as antihypertensive, gastro-protective, nephroprotective, antioxidant, antimicrobial, Geno protective, neuroprotective, immunomodulatory, anti-inflammatory, hypoglycemic, hypolipidemic, anti-carcinogenic and hepato-protective [5,6].

$N$. sativa seeds with some active components such as essential oil, thymoquinone, p-cymene, and thymol are very rich in the fixed oil, essential fatty acids, alkaloids, phytosterols, glycolipids and phospholipids, saponins, and essential oil components. Thymoquinone (TQ) is a cytotoxic agent in many human tumor cell lines that seem to be immune to particular multi drugs [7]. There is evidence that most

\footnotetext{
* Corresponding author:

Mohammad Asadul Habib, MSc

Department of Food Technology and Nutrition Science,

Noakhali Science and Technology University, Bangladesh

Tel/Fax: +8801847-102071

Email: asadulhabib698@gmail.com

http://orcid.org/oooo-0003-2331-7871
}

Received: November, 24, 2020
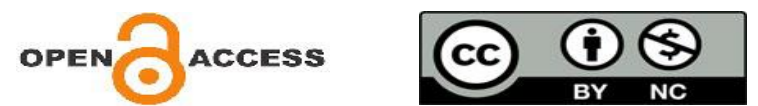

Accepted: December, 04, 2020 
of $N$. sativa's therapeutic effects are due to the influence of TQ which has been the sativa's greatest bioactive component. Crude and TQ against noncommunicable diseases (cardiovascular disease, obesity, hypertension, diabetes, cancer, etc.) are beneficial from their seeds and oil, and communicable diseases (malaria, AIDS, hepatitis C virus, fungal, viral, parasitic infections, etc.) [8]. TQ had already observed pleiotropic anti-cancer effects, including chemo potentiation, anti-inflammation, immunomodulation, as well as radiosensitization [9].

In addition to inducing apoptosis across several different cancers, TQ has been shown to inhibit numerous tumorigenic signaling nodes, such as those involved in cell proliferation, epithelial to mesenchymal shift, invasive cell migration, and metastasis [10]. In this study, it was aimed to show the positive effects of $N$. sativa against human cancer.

\section{Materials and Methods}

\subsection{Literature search}

The reporting of this review follows the Preferred Reporting Items for Systematic Reviews and MetaAnalyses (PRISMA) statement. We searched PubMed, Cochrane library, Semantic scholar, and directory of open access journal (DOAJ) databases for studies from 1983 to 2020 before May. For gray articles, we searched open grey (www.opengrey.eu) and grey literature reports (www.greylit.org). The keywords used for searching (Nigella sativa OR Black cumin OR Black seed OR Kalonji) AND (Cancer OR Tumor OR Malignancy) to identify intervention studies investigating the effect of black cumin on cancer.

\subsection{Study selection and data extraction}

In this systematic review, we included published intervention studies (these include randomized controlled trials, clinical trials, and placebo-controlled trials), reporting the effect of black cumin on cancer and published in English). Trials were excluded if they did not meet the criteria above and were involved in animal studies or in vitro studies, did not use the interests of intervention or outcome. Two independent reviewers (MAH and AIC) screened the titles and abstracts of the initially identified studies to determine whether they would satisfy the selection criteria. Any disagreements about selection were resolved through consensus or consultation with a third author (TR). The data collection form included questions on the year of publication, geographic origin, types of intervention, doses, patients' type and characteristics (sample size, age, etc.). Figure 1 summarizes the study selection process.

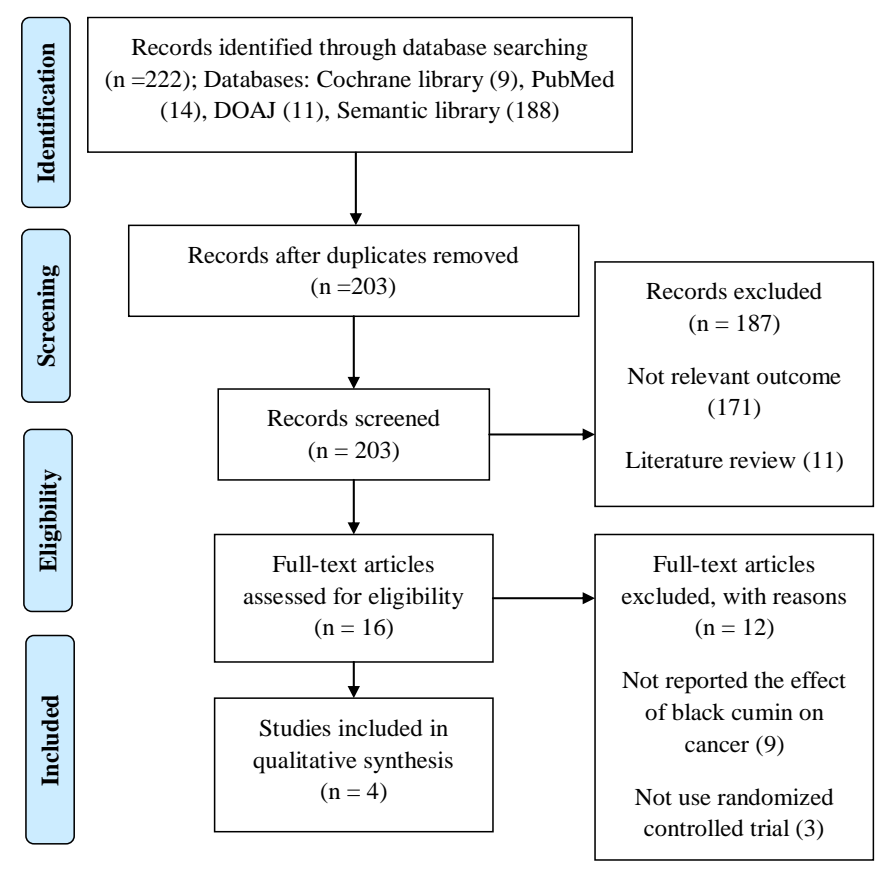

Figure 1: Flow diagram of study selection

\subsection{Quality assessment}

The quality of each study was assessed by following the Cochrane format [11] reported in Table 1 . The quality assessed for each study are (1) quality of randomization, (2) quality of blinding, and (3) quality of the description of withdrawals and dropouts.

\section{Results}

We selected four human studies (Table 2) that described the effect of $N$. sativa on human cancer [1215]. In three days, Behnamfar et al. analyzed the incidence and magnitude of phlebitis, applying $N$. Sativa by a catheter upon the peripheral vein. In their research, they reported that the prevalence of phlebitis in the control group was optimum and that the occurrence of phlebitis in the intervention group was lowest during the 72 hours of the test, assuming that $N$. sativa oil seemed to have a massive effect on the intervention group [12]. Hussain et al. demonstrated the effect of applying $N$. sativa oil on acute myeloid leukemia. The primary result of this research concluded that at the end of 28 days, the severity of 
Table 1. Assessment of study quality for selected studies

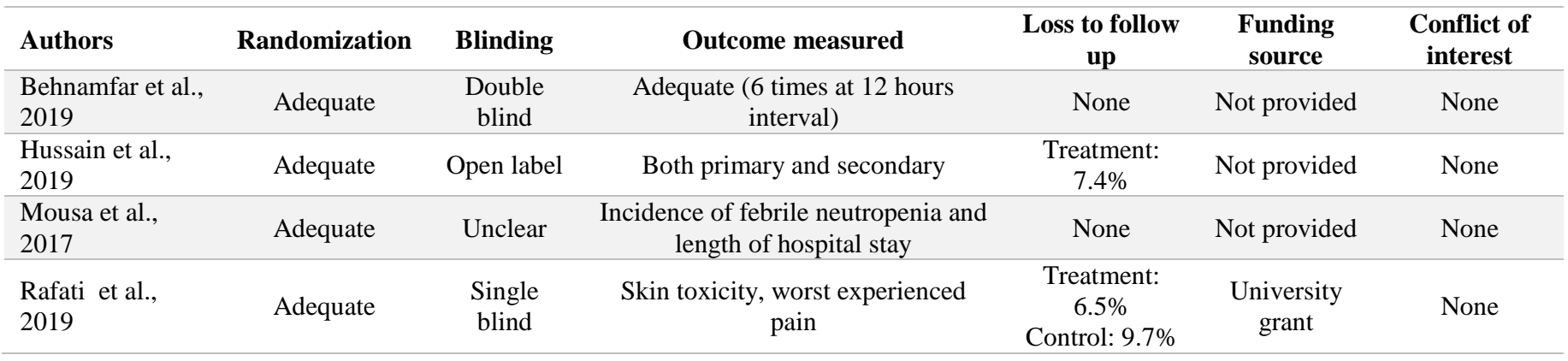

Table 2. Characteristics of studies included for systematic review examining effect of $N$. sativa on cancer

\begin{tabular}{|c|c|c|c|c|c|c|c|c|}
\hline Authors & Country & Study design & Subjects & Measures & $\begin{array}{c}\text { Dose } \\
\text { intake }\end{array}$ & Main result & Comment & Ref \\
\hline $\begin{array}{l}\text { Behnamfar et } \\
\text { al., } 2019\end{array}$ & Iran & $\begin{array}{l}\text { Randomized } \\
\text { single blind } \\
\text { control trial }\end{array}$ & $\begin{array}{l}60 \text { patients having } \\
\text { gastrointestinal } \\
\text { cancers, } 30 \text { in } \\
\text { treated group, } 30 \text { in } \\
\text { control group }\end{array}$ & N. sativa oil & $\begin{array}{l}5 \text { drops } \\
\text { of } N . \\
\text { sativa oil } \\
\text { applied } 2 \\
\text { times a } \\
\text { day }\end{array}$ & $\begin{array}{l}\text { There is no significant } \\
\text { difference between } \\
\text { the groups in terms of } \\
\text { phlebitis incidence } \\
\text { and severity }\end{array}$ & $\begin{array}{l}\text { Result analyzed by } \\
\text { Chi-square test, } \\
\text { Fisher's exact test } \\
\text { and Mann-Whitney } \\
\text { test }\end{array}$ & 12 \\
\hline $\begin{array}{l}\text { Hussain et al., } \\
2019\end{array}$ & Iraq & $\begin{array}{c}\text { Randomized } \\
\text { open-label } \\
\text { controlled study }\end{array}$ & $\begin{array}{l}54 \text { patients having } \\
\text { acute myeloid } \\
\text { leukemia, } 27 \text { in } \\
\text { treated group, } 27 \text { in } \\
\text { control group }\end{array}$ & N. sativa oil & $\begin{array}{c}10 \mathrm{ml} / 6 \\
\text { hours }\end{array}$ & $\begin{array}{c}\text { Oral } \\
\text { Mucositis Assessment } \\
\text { Scale (OMAS) score } \\
\text { was significantly } \\
\text { lower in N. sativa oil } \\
\text { group compared with } \\
\text { control group }\end{array}$ & $\begin{array}{l}\text { Result analyzed by } \\
\text { chi-square test, } \\
\text { Fisher's exact test, } \\
\text { Mann-Whitney test, } \\
\text { and } \\
\text { Kruskal-Wallis test }\end{array}$ & 13 \\
\hline $\begin{array}{l}\text { Mousa et al., } \\
2017\end{array}$ & Egypt & $\begin{array}{l}\text { Randomized } \\
\text { pretest-post-test } \\
\text { control group } \\
\text { study }\end{array}$ & $\begin{array}{l}80 \text { patients having } \\
\text { primary brain } \\
\text { tumors undergoing } \\
\text { chemotherapy }\end{array}$ & $\begin{array}{l}\text { N. sativa } \\
\text { seeds }\end{array}$ & $5 \mathrm{~g} /$ day & $\begin{array}{l}\text { The incidence febrile } \\
\text { neutropenia } \\
\text { significantly } \\
\text { decreased }(\mathrm{p}<0.001) \\
\text { in } N \text {. sativa } \text { seed } \\
\text { group compared with } \\
\text { control group }\end{array}$ & $\begin{array}{c}\text { Result analyzed by } \\
\text { two-way ANOVA } \\
\text { using Bonferroni } \\
\text { correction, Monte- } \\
\text { Carlo exact test } \\
\text { (MCP) } \\
\text { and Fisher's exact } \\
\text { test (FEP) }\end{array}$ & 14 \\
\hline $\begin{array}{l}\text { Rafati et al., } \\
2019\end{array}$ & Iran & $\begin{array}{c}\text { Randomized } \\
\text { double blind } \\
\text { control trial }\end{array}$ & $\begin{array}{l}62 \text { patients having } \\
\text { breast cancer, } 31 \text { in } \\
\text { intervention group, } \\
31 \text { in control group }\end{array}$ & N. sativa gel & $\begin{array}{l}5 \% N . \\
\text { sativa } \\
\text { gel } \\
\text { applied } \\
\text { twice } \\
\text { daily }\end{array}$ & $\begin{array}{c}\text { The development of } \\
\text { acute radiation } \\
\text { dermatitis and moist } \\
\text { desquamation were } \\
\text { lower in N. sativa } \\
\text { gel compared with } \\
\text { those who used the } \\
\text { placebo }\end{array}$ & $\begin{array}{l}\text { Result analysed by } \\
\text { the Kaplan-Meier } \\
\text { method with the } \\
\text { Log-Rank test, the } \\
\text { generalized } \\
\text { estimating equations } \\
\text { (GEE) method }\end{array}$ & 15 \\
\hline
\end{tabular}


oral mucositis was significantly lower in the $N$. sativa oil group compared with the control group. Indeed, the incidence of erythematic and ulceration among the N. sativa oil community was lower. At the end of 12 days, pain severity among the N. sativa oil group dropped considerably compared with the control group. The secondary outcome of this study mentioned that salivary TNF-a was substantially lowered by the use of $N$. sativa oil mouth rinse on day 18 and day 28 compared to the control group but salivary IL-6 was not considerably different in the $N$. sativa oil control samples compared to the corresponding group ( $\mathrm{p}>0.05$ ) [13]. Mousa et al. in their study found that maximum children took $N$. sativa for 3-9 months (average of 6 months) and loss of body weight was less severe in the intervention group than the control group $(\mathrm{p}=0.048)$. The intervention group of children experienced less febrile neutropenia (2.2\%) than the control group (19.3\%). The percentage of febrile neutropenia among medulloblastoma (MB) and children with primitive neuroectodermal tumors were higher among the control group than the intervention group. In the case of hematological toxic effects, there have been statistically significant disparities in the occurrence of neutropenia $(\mathrm{p}=0.001)$ and febrile neutropenia $(p=0.001)$ between both the intervention group and the control group, but the incidence of anemia, thrombocytopenia, and leucopenia was not significantly different in both groups [14].

Rafati et al. established how acute radiation dermatitis might have been eliminated in breast cancer by applying $N$. sativa gel. The incidence of skin toxicity in the $N$. sativa gel group was significantly lower at weeks 3,4 , and 5 compared to the control group even though there were significant differences between the two groups in the size and severity of moist desquamation. The worst perception of pain among the control group was substantially higher than that of the $N$. sativa gel group ( $\mathrm{p}<0.05)$. There was no dramatic difference in the skin-related quality of life between the two classes [15].

\section{Discussion}

The present review showed the effects of black cumin on different types of cancer. Anticancer activity of N. sativa was described in a study where certain TQ (a chemical component of black cumin) had been used to manipulate phosphatase and tensin homolog
(PTEN) expression and induce apoptosis in human breast cancer cells. In this study, it was found that TQ significantly inhibits the proliferation of DOX cells. It, therefore, triggered apoptosis and protein p53, and even some up-regulated PTEN by inhibiting the Akt pathway [16]. Another mouse study showed that TQ induced cytotoxicity and apoptosis, and also inhibited tumor growth [17]. TQ induces apoptosis and disrupts mitochondrial membrane potentials. It also activates the caspases 3,8 , and 9 in HL-6o cells to treat myeloblastic leukemia, thus showing its effect on myeloblastic leukemia [18]. TQ indicates significant cytotoxicity for cancer of such bladder. It prevents the rapid multiplication of cancer cells, and by activating caspases induces apoptosis. TQ's anticancer effect resulted in endoplasmic reticulum stress pathway activation and mitochondrial dysfunctions. It also boosted the Bcl-2 anti-apoptotic protein and blocked cytochrome $\mathrm{C}$ entrance [19]. TQ inhibited renal cell cancer (RCC) via cell migration, invasion, and epithelial-mesenchymal shift. This also increased the expression of E-cadherin and the level of hepatic kinase B1 phosphorylation was considerably upregulated following thymoquinone therapy [20, 21]. TQ protects against the development of prostate cancer. It was found to inhibit the growth of DU145 and $\mathrm{PC}_{3}$ cells which caused prostate cancer by treating with TQ. TQ dramatically inhibits the DU145 and PC3 cell migration $(\mathrm{p}<0.05)$. The expression of epithelialmesenchymal transition (EMT) markers in prostate cancer cells have also been repressed, and TGF- $\beta$, Smad2, and Smad3 expression have also been minimized with TQ [22].

The article has some strengths and limitations. Using proper guidelines of the systematic review and quality assessment of the selected studies are the strengths of the articles. Some limitations of the article are only used article published in English and had fulltext availability.

N. sativa component potential anticancer activities have been identified thousands of years ago but appropriate scientific research with this essential traditional medicine is a very recent story. According to the limited evidence from the study, black cumin may have favorable effects on human cancer and tumor. It is worth emphasizing further research work behind this because it is a safe and effective anticancer agent. In particular, researchers should evaluate the active compounds more broadly, as very few authentic 
reports are available on the chemical composition of seeds or $N$. sativa exists. Also, more importance should be placed to investigate the appropriate molecular pathways of TQ and other components on different cancers as the current understandings are largely unclear.

Regarding the potential benefits of $N$. sativa on cancer, the anti-carcinogenic effects of $N$. sativa remained assessed through restricted clinical trials lacking a placebo community. For ongoing studies, it was recommended that further double-blind, placebocontrolled randomized clinical trials test the impact of N. sativa on cancer diagnosis and prevention.

\section{Author Contributions}

MAH: Designed the study and final manuscript preparation; AIC: Conceived, and final manuscript preparation; MA: Designed the final data, tables, and graphs, conducted the experiment; TR: Conceived and final approval of the manuscript.

\section{Conflict of Interest}

The author declares no competing interest.

\section{Ethical declarations}

The study was approved by the ethics board of Noakhali Science and Technology University.

\section{Financial Support}

None.

\section{References}

1. Akram Khan M, Afzal M. Chemical composition of Nigella sativa Linn: Part 2 Recent advances. Inflammopharmacology. 2016; 24(2-3):67-79.

2. De Luca V, Salim V, Atsumi SM, Yu F. Mining the biodiversity of plants: a revolution in the making. Science. 2012; 336(6089):165861.

3. Takruri HRH, Dameh MAF. Study of the nutritional value of black cumin seeds (Nigella sativaL). J Sci Food Agric. 1998; 76(3):404-10.

4. Ramadan MF. Nutritional value, functional properties and nutraceutical applications of black cumin (Nigella sativa L.): an overview. Int J Food Sci Technol. 2007; 42(10):1208-18.

5. Mosbah R, Djerrou Z, Mantovani A. Protective effect of Nigella sativa oil against acetamiprid induced reproductive toxicity in male rats. Drug Chem Toxicol. 2018; 41(2):206-12.

6. Hashem MA, Mohamed WAM, Attia ESM. Assessment of protective potential of Nigella sativa oil against carbendazimand/or mancozeb-induced hematotoxicity, hepatotoxicity, and genotoxicity. Environ Sci Pollut Res Int. 2018; 25(2):1270-82.

7. Yuksel S, Tasdemir S, Korkmaz S. Protective effect of thymoquinone against cyclophosphamide-induced genotoxic damage in human lymphocytes. Bratisl Lek Listy. 2017; 118(4):208-11.

8. Habib MA, Afroze M, Islam MF, Sajid M, Chowdhury AI, Ahmed N. Nigella sativa: A Traditional Remedy for the Prevention of Non-Communicable and Communicable Diseases. Sch Int J Tradit Complement Med. 2020; 3(7):149-56.

9. Mostofa AGM, Hossain MK, Basak D, Bin Sayeed MS. Thymoquinone as a Potential Adjuvant Therapy for Cancer Treatment: Evidence from Preclinical Studies. Front Pharmacol. 2017; 8:295.

10. Asaduzzaman Khan M, Tania M, Fu S, Fu J. Thymoquinone, as an anticancer molecule: from basic research to clinical investigation. Oncotarget. 2017; 8(31):51907-19.

11. Higgins J, Green S. Cochrane Handbook for Systematic Reviews of Interventions. Version 5.1.0. [updated March 2011]. The Cochrane Collaboration. Available at: https://handbook-51.cochrane.org/.

12. Behnamfar N, Parsa Yekta Z, Mojab F, Kazem Naeini SM. The effect of nigella sativa oil on the prevention of phlebitis induced by chemotherapy: a clinical trial. Biomedicine (Taipei). 2019; 9(3):20. 13. Hussain SA, Mohammed Ameen HA, Mohammed MO, Ahmed KM, Hama-Gareb Ali R, Safar BM, et al. Nigella sativa Oil Mouth Rinse Improves Chemotherapy-Induced Oral Mucositis in Patients with Acute Myeloid Leukemia. Biomed Res Int. 2019; 2019:3619357.

14. Mousa HFM, Abd-El-Fatah NK, Darwish OA, Shehata SF, Fadel SH. Effect of Nigella sativa seed administration on prevention of febrile neutropenia during chemotherapy among children with brain tumors. Childs Nerv Syst. 2017; 33(5):793800 .

15. Rafati M, Ghasemi A, Saeedi M, Habibi E, Salehifar E, Mosazadeh M, et al. Nigella sativa L. for prevention of acute radiation dermatitis in breast cancer: A randomized, double-blind, placebo-controlled, clinical trial. Complement Ther Med. 2019; 47:102205.

16. Arafa el SA, Zhu Q, Shah ZI, Wani G, Barakat BM, Racoma I, et al. Thymoquinone up-regulates PTEN expression and induces apoptosis in doxorubicin-resistant human breast cancer cells. Mutat Res. 2011; 706(1-2):28-35.

17. Şakalar Ç, İzgi K, İskender B, Sezen S, Aksu H, Çakır M, et al. The combination of thymoquinone and paclitaxel shows antitumor activity through the interplay with apoptosis network in triple-negative breast cancer. Tumour Biol. 2016; 37(4):4467-77. 18. Effenberger K, Breyer S, Schobert R. Terpene conjugates of the Nigella sativa seed-oil constituent thymoquinone with enhanced efficacy in cancer cells. Chem Biodivers. 2010; 7(1):129-39.

19. Zhang M, Du H, Huang Z, Zhang P, Yue Y, Wang W, et al. Thymoquinone induces apoptosis in bladder cancer cell via endoplasmic reticulum stress-dependent mitochondrial pathway. Chem Biol Interact. 2018; 292:65-75.

20. Zhang Y, Fan Y, Huang S, Wang G, Han R, Lei F, et al. Thymoquinone inhibits the metastasis of renal cell cancer cells by inducing autophagy via AMPK/mTOR signaling pathway. Cancer Sci. 2018; 109(12):3865-73.

21. Kou B, Kou Q, Ma B, Zhang J, Sun B, Yang Y, et al. Thymoquinone inhibits metastatic phenotype and epithelial-mesenchymal transition in renal cell carcinoma by regulating the LKB1/AMPK signaling pathway. Oncol Rep. 2018; 40(3):1443-50. 


\section{Habib et al.}

22. Kou B, Liu W, Zhao W, Duan P, Yang Y, Yi Q, et al. Thymoquinone inhibits epithelial-mesenchymal transition in prostate cancer cells by negatively regulating the TGF- $\beta / \mathrm{Smad} 2 / 3$ signaling pathway. Oncol Rep. 2017; 38(6):3592-8. 